\title{
Laparoscopic Dorsal Rectopexy with Pelvic Peritoneal Sac Excision for Rectal Prolapse: Video Vignette
}

\section{Rektal Prolapsusta Pelvik Peritoneal Kese Eksizyonu ile Laparoskopik Dorsal Rektopeksi: Video Vinyet}

\author{
(1) Fevzi Cengiz, (1) Nihan Acar, (1) Turan Acar, (1) Feyyaz Güngör, () Erdinç Kamer \\ İzmir Katip Çelebi University, Atatürk Training and Research Hospital, Clinic of General Surgery, İzmir, Turkey
}

\section{HIIIIII| ABSTRACT}

Rectal prolapse is a pelvic floor disorder characterised by the protrusion of the rectum through the anal canal. Although its definite treatment is via surgery, an ideal surgical technique has not yet been introduced. Laparoscopic mesh rectopexy has been reported to provide a low recurrence rate and better functional outcomes. This technique can be performed with both the anterior or posterior fixation of the mesh.

Herein, we present a video demonstrating the procedure of laparoscopic dorsal rectopexy and peritoneal sac excision in a 62-year-old male with RP. Keywords: Dorsal mesh rectopexy, posterior rectopexy, rectal prolapse

\section{||||||||||| ÖZ}

Rektal prolapsus, rektumun anal kanaldan dışarı çıkması ile karakterize bir pelvik taban hastalığıdır. Kesin tedavisi cerrahi olmakla birlikte, ideal cerrahi teknik henüz tanımlanmamıştır. Laparoskopik yama rektopeksinin, düşük rekürrens oranı ve daha iyi fonksiyonel sonuçlar sağladığı bildirilmiştir. Bu teknik, yamanın hem anterior hem de posterior tespiti ile gerçekleştirilebilir.

Burada, rektal prolapsus tanılı 62 yaşındaki bir erkek hastada, laparoskopik dorsal rektopeksi ve peritoneal kesenin eksizyonu prosedürünü gösteren bir video sunulmaktadır.

Anahtar Kelimeler: Dorsal yama rektopeksi, posterior rektopeksi, rektal prolapsus

\section{Introduction}

Rectal prolapse (RP) is a pelvic floor disorder characterised by the protrusion of the rectum through the anal canal. Its definite treatment is by surgery, which can be implemented either through the perineal or abdominal approach. Several procedures regarding the abdominal approach have been introduced in the literature. Rectopexy as an abdominal approach is performed using sutures and mesh, with or without colonic resection. The ideal treatment approach varies according to patient's age, gender, grade of the prolapse, anal tonus, presence of other accompanying pelvic floor disorders and the operative conditions., ${ }^{1,2}$ Mesh rectopexy provides a low recurrence rate, but may also lead to some complications (i.e. pelvic infection, erosion to the luminal organs and dislodgement) related to the foreign body. ${ }^{3}$ The outcomes and advantages of anterior and posterior fixation of the mesh are also comparable. Although their recurrence rates were similar, posterior rectopexy is considered to have a lower rate of stricture and postoperative constipation than anterior rectopexy. ${ }^{4}$

Herein, we present a video demonstrating the procedure of laparoscopic dorsal rectopexy and peritoneal sac excision in a 62-year-old male with RP. The patient was admitted with the complaint of bowel prolapse outside the anus, occurring after defecation and requiring manual reduction. Physical examination revealed a normal anal tonus and 
Oxford Grade V RP. Colonoscopic examination was normal. Magnetic resonance defaecography showed oedema in the rectosigmoid colon, moderate rectal descensus, pelvic floor dysfunction and dyssynergic defaecation. The decision to perform a laparoscopic rectopexy for this patient was made based on these findings. The four-trocar technique was applied. During the laparoscopic exploration, the pelvic peritoneal sac was found to be elongated and significantly thickened than usual due to chronic prolapse. The rectum was mobilized to the pelvic floor, and the lateral ligaments were preserved in order to avoid postoperative constipation. A rectangular polypropylene mesh of $15 \times 5 \mathrm{~cm}$ was prepared and secured to the sacral promontory with a tacker. The elongated peritoneal sac was excised using an energy device in order to provide fibrosis and stabilization of the rectum. Then, a dorsal rectopexy was performed by fixing the mesh to the posterior wall of the rectum using separate polydioxanone (PDS) sutures (Video). The procedure was completed uneventfully, and the patient was discharged on the fourth postoperative day. In the first year of followup, there was no evidence of recurrence or any long-term complication.

Laparoscopic dorsal rectopexy is a safe and feasible technique in the treatment of RP, but a tailored approach for each patient should be adopted as in all techniques. Excision of the peritoneal sac, especially in cases where it is significantly loose and elongated, can be performed when its benefits are considered.
Informed Consent: Obtained.

Peer-review: Externally peer review.

\section{Authorship Contributions}

Surgical and Medical Practices: F.C., N.A., Concept: F.C., N.A., T.A., E.K., Design: N.A., E.K., Data Collection or Processing: F.C., T.A., F.G., Analysis or Interpretation: N.A., F.G., Literature Search: F.C., N.A., F.G., Writing: F.C., N.A., E.K.

Conflict of Interest: No conflict of interest was declared by the authors.

Financial Disclosure: The authors declared that this study received no financial support.

\section{References}

1. Acar T, Acar N, Güngör F, Sür Y, Haciyanli M. Laparoscopic ventral mesh rectopexy for male patient with rectal prolapse - a video vignette. Colorectal Dis. 2019;21(8):979-980

2. Acar N, Ballı G, Khabbazazar D, Cengiz F, Acar T, Dilek ON. Emergency perineal rectosigmoidectomy (Altemeier procedure) for strangulated rectal prolapse - a video vignette. Colorectal Dis. 2019;21(5):608-609.

3. Tade AO, Olatunji AO. Mesh-free Ventral Rectopexy for Women with Complete Rectal and Uterovaginal Prolapse. J Surg Tech Case Rep 2012;4(2):89-91.

4. Hamel CT, Wexner SD. Rectal prolapse. In: Holzheimer RG, Mannick JA, editors. Surgical Treatment: Evidence-Based and Problem-Oriented. Munich: Zuckschwerdt; 2001. Available from: https://www.ncbi.nlm.nih. gov/books/NBK6929/.

\section{Video 1.}

https://www.doi.org/10.4274/tjcd.galenos.2020.2020-6-10.videol 